\title{
Innovációs lehetőségek a medicinában: 3D tervezési és 3D nyomtatási lehetőségek a felnőtt szív- és mellkassebészeti betegellátásban
}

\author{
Magyarországi tapasztalatok
}

\author{
Barabás János Imre dr. ${ }^{1,7}$. Ghimessy Áron Kristóf dr. ${ }^{3,4}$ \\ Rényi-Vámos Ferenc dr. ${ }^{3,4}$. Kocsis Ákos dr. ${ }^{3,4}$. Agócs László dr. ${ }^{3,4}$ \\ Mészáros László dr. ${ }^{3,4}$. Pukacsik Dávid dr. ${ }^{5}$ \\ Andi Judit dr. ${ }^{6}$ - Laki András dr. ${ }^{7,8}$ - Vörös Fanni dr. ${ }^{2}$ \\ Hartyánszky István dr. ${ }^{1}$ - Panajotu Alexis dr. ${ }^{1}$ - Fazekas Levente dr. ${ }^{1,3}$ \\ Szabolcs Zoltán dr. ${ }^{1}$ - Merkely Béla dr. ${ }^{1}$

\footnotetext{
${ }^{2}$ Semmelweis Egyetem, Általános Orvostudományi Kar, Budapest

${ }^{3}$ Semmelweis Egyetem, Általános Orvostudományi Kar, Mellkassebészeti Klinika, Budapest

${ }^{4}$ Országos Onkológiai Intézet, Mellkassebészeti Osztály, Budapest

${ }^{5}$ Országos Onkológiai Intézet, Emlő- és Lágyrészsebészeti Osztály, Budapest

${ }^{6}$ Országos Onkológiai Intézet, Onkológiai Képalkotó és Invazív Diagnosztikai Központ, Budapest

${ }^{7}$ Pázmány Péter Katolikus Egyetem, Információs Technológiai és Bionikai Kar, Budapest

${ }^{8}$ Semmelweis Egyetem, Általános Orvostudományi Kar, Biofizikai és Sugárbiológiai Intézet, Budapest
} \\ ${ }^{1}$ Semmelweis Egyetem, Általános Orvostudományi Kar, Városmajori Szív- és Érgyógyászati Klinika, Budapest
}

\begin{abstract}
A 3D tervezés és 3D nyomtatás nyújtotta lehetőségek folyamatosan bővülnek az orvosi gyakorlatban. A technológia leggyakoribb felhasználási területe a 3D anatómiai modellek nyomtatása sebészi döntéstámogatás céljából. Az így személyre szabott és kinyomtatott modelleknek számos egyéb felhasználási területük van: komplex anatómiai szituációk pontos megjelenítése, az adott beteg sebészi beavatkozásának szimulációja a tényleges beavatkozást megelőzően, betegoktatás és a különböző diszciplínák között az eset megbeszélésének megkönnyítése. A technológia szívsebészeti vonatkozásában kiemelendő a kamrákat és a nagyereket érintő elváltozások 3D anatómiai modellezése és funkcionális elemzése, míg a mellkassebészetben az onkológiai betegek erősen vaszkularizált tumorának eradikálásakor lehet a sebészi terápia felállításában szerepe. A virtuális és 3D nyomtatott modellek új diagnosztikai lehetőséget jelentenek, melyek segítségével egyes sebészi beavatkozások standardizálhatók, így személyre szabott terápiás döntéseket lehet kidolgozni. A 3D projekt a Semmelweis Egyetemen 2018-ban kezdődött a Semmelweis Egyetem Városmajori Szív- és Érgyógyászati Klinikájának és az Országos Onkológiai Intézet Mellkassebészeti Osztályának kooperációja során. A szerzók a technológia ismertetése mellett az eddigi 121 tervezés és 49 személyre szabott 3D nyomtatás során megszerzett tapasztalataikat és a technológia orvosi szempontból való előnyeit ismertetik.

Orv Hetil. 2019; 160(50): 1967-1975.
\end{abstract}

Kulcsszavak: 3D tervezés, 3D nyomtatás, mútéti tervezés, kardiológiai tervezés, mellkasi mútét tervezése

Innovation in medicine: opportunities of 3D modeling and printing for perioperative care of cardio and thoracic surgical patients

\section{Experiences in Hungary}

Use of 3D planning and 3D printing is expanding in healthcare. One of the common applications is the creation of anatomical models for the surgical procedure from DICOM files. These patient-specific models are used for multiple purposes, including visualization of complex anatomical situations, simulation of surgical procedures, patient educa- 
tion and facilitating communication between the different disciplines during clinical case discussions. Cardiac and thoracic surgical applications of this technology development include the use of patient-specific 3D models for exploration of ventricle and aorta function and surgical procedural planning in oncology. The 3D virtual and printed models provide a new visualization perspective for the surgeons and more efficient communication between the different clinical disciplines. The 3D project was started at the Semmelweis University with the cooperation of the Thoracic Surgery Department of the National Institute of Oncology in 2018. The authors want to share their experiences in $3 \mathrm{D}$ designed medical tools.

Keywords: 3D modeling, 3D printing, surgical planning, cardiac surgery, thoracic surgery

Barabás JI, Ghimessy ÁK, Rényi-Vámos F, Kocsis Á, Agócs L, Mészáros L, Pukacsik D, Andi J, Laki A, Vörös F, Hartyánszky I, Panajotu A, Fazekas L, Szabolcs Z, Merkely B. [Innovation in medicine: opportunities of 3D modeling and printing for perioperative care of cardio and thoracic surgical patients. Experiences in Hungary]. Orv Hetil. 2019; 160(50): 1967-1975.

(Beérkezett: 2019. július 27.; elfogadva: 2019. augusztus 26.)

\section{Rövidítések}

3D = háromdimenziós; $\mathrm{CT}=$ (computed tomography) számítógépes tomográfia; DICOM = (digital imaging and communications in medicine) digitális képkezelés és kommunikáció az orvostudományban; DMLS = (direct metal laser sintering) közvetlen lézersugaras fémszinterezés; FDM = (fused deposition modeling) ömledékrétegezési technológia; MIT = (Massachusetts Institute of Technology) Massachusettsi Múszaki Egyetem; MRI = (magnetic resonance imaging) mágnesesrezonancia-képalkotás; ROI = (region-of-interest) kijelölési terület; SLS = (selective laser sintering) szelektív lézeres szinterezés; STL $=$ (Standard Triangle Language) geometriai fájlformátum, amely a modell felületét közelítő háromszögek segítségével írja le

A 3D tervezés és a tervezésből készíthető 3D nyomtatott modellek az 1980-as évek óta elérhető technológiák. A 3D nyomtatást mint eljárást az MIT (Massachusetts Institute of Technology) kutatói fejlesztették ki, fóleg ipari gyártási prototípusok elóállítására. A technológia elterjedése azonban mindössze az elmúlt tíz évre tehető. Ennek egyik oka, hogy a 3D modellek készítése magas számítási igényeket követelt, mely feladatokhoz speciális számítástechnikai eszközökre volt szükség. A következő problémát a 3D nyomtatás technológiai fejletlensége jelentette. A technológia fejlődése azonban lehetővé tette a magas számítási kapacitású számítógépek átlagos felhasználását, illetve az asztali méretű 3D nyomtatók megjelenését. Következésképpen ezen fejlesztések elterjedése lehetővé tette a különböző tudományterületek előtt a 3D tervezés és nyomtatás alkalmazásának lehetőségét [1].

A technológia orvosi szempontból történő hasznosítása az elmúlt öt évben vette kezdetét. A PubMed adatbázisban a 3D tervezés és 3D nyomtatás kulcsszavakra keresve (3D modeling [Title/Abstract] OR 3D printing [Title/Abstract]) [2] 2014-től exponenciális ugrást figyelhetünk meg (1. ábra). Az első témában íródott pub-

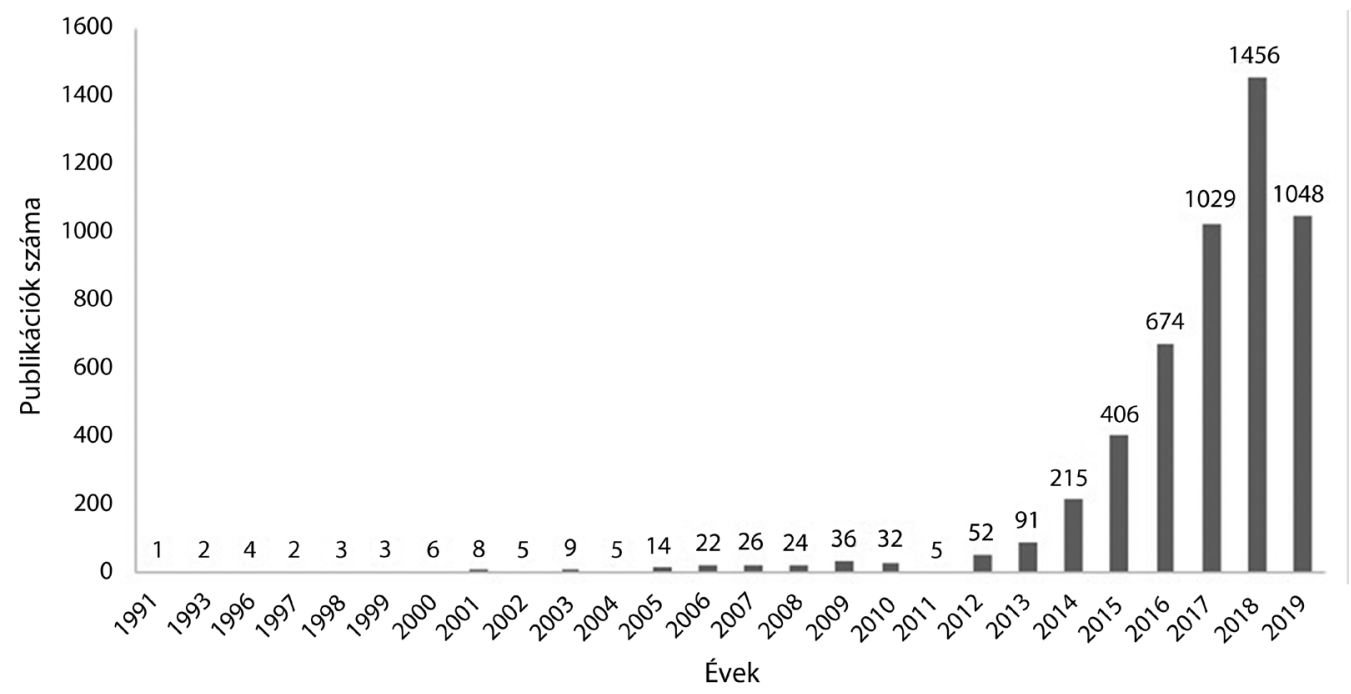

\begin{tabular}{l|l} 
1. ábra & $\begin{array}{l}\text { A publikációk számának alakulása a 3D technológia orvosi alkalmazásának területén } \\
\text { Magyarázat: A PubMed adatbázisban a keresési metódust a cikkben olvashatja [2], a 2019. július 25-i adatbázis alapján. }\end{array}$
\end{tabular} 


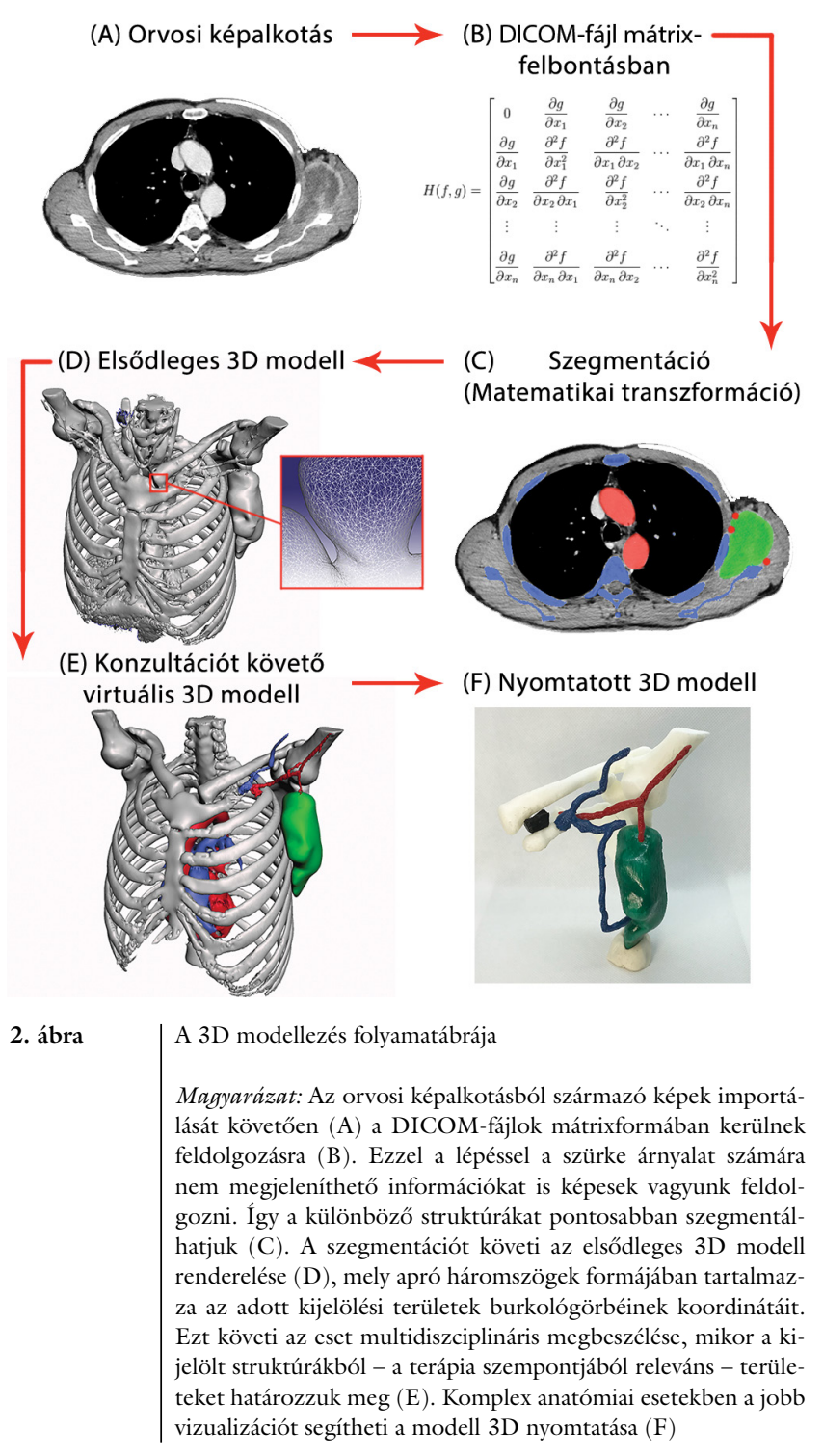

likációt 1991-ben Stiehl JB, a Wisconsin Egyetem professzora közölte: ortopédiai betegüknél acetabulum rekonstrukcióját végezték 3D tervezés segítségével [3]. Ekkor még nem DICOM-fájlokkal dolgoztak, hanem a röntgenképekból nyert méretarányok segítségével rekonstruálták az acetabulumot, és egy gipszből kiöntött forma segítségével végezték a 3D tervezést. Mára a technika sokat fejlődött, az újonnan kialakult diszciplína relevanciáját az orvosi kutatásban és a betegellátásban az is bizonyítja, hogy 2018-ban több mint 1400, újonnan megjelent cikk foglalkozott ezzel a mérnöki és orvosi határterülettel.

A szerző́k célja, hogy a 3D tervezés és nyomtatás technológiai hátterét ismertessék, illetve alkalmazásuk tapasztalatait összegezzék, és ezen fejlesztések eredményét bemutassák a Semmelweis Egyetem Városmajori Szív- és Érgyógyászati Klinikájának és az Országos Onkológiai Intézet Mellkassebészeti Osztályának gyakorlatában.

\section{Módszer}

\section{Orvosi képalkotás - DICOM-fájlok}

Az orvosi képalkotás során készült képek adatai számos lépésen mennek keresztül, mire személyre szabott 3D modelleket tervezünk, illetve nyomtatunk (2. ábra). A 3D tervezés és nyomtatás első lépése a megfelelő CT-, MRI- vagy ultrahangképek készítése. Az elkészült képek DICOM-kiterjesztésben tárolják az orvosi képalkotás adatait. Ezen fájltípusok matematikai értelemben mátrixrendszerben tartalmazzák az adott szürke árnyalathoz (CT-képeknél Hounsfield-egység, MRI-képeknél intenzitás, míg ultrahang esetén denzitás) tartozó koordinátaadatokat. A mátrix jelen esetben horizontális síkok szummációja, mely a z-tengely mentén rétegről rétegre képezi le a vizsgált szervet vagy szervrendszereket. A mátrixok egyes cellái azonban több információt tartalmaznak, mint amennyit a rutin orvosi képmegjelenítésben látunk, illetve a konvencionális 3D megjelenítésre alkalmas szoftverek használnak. Az adatok további matematikai alakításával (képfeldolgozási algoritmusok és áramlástani végeselem-analízis alkalmazása) dinamikus 3D modelleket lehet létrehozni, és funkcionális analíziseket lehet végezni a modelleken, ami új lehetőségeket nyit a betegellátásban és a kutatásban [4].

\section{Képfeldolgozás - Szegmentáció}

Szegmentációnak nevezzük a képi adatok számítástechnikai feldolgozását, amikor funkcionális egységeket jelölünk ki az egymást követó horizontális rétegeken. Így az egyes képeken kizárólag azok a területek kerülnek kijelölésre, amelyek a 3D tervezés tárgyát képezik. Ezt a területet kijelölési területnek (region-of-interest, ROI) nevezzük, amely lehet egyetlen szerv, például egy jobb oldali tüdő, vagy akár egy komplex anatómiai struktúra: a szív congenitalis malformatiója [5]. Ennek a területnek a kijelölése három módon történhet: manuálisan, automatikusan vagy szemiautomatikusan (3. ábra).

- Manuális szegmentációnál minden rétegen kézzel, külön-külön megyünk végig és jelöljük ki a 3D modellezni kívánt struktúrát. Ennek a szegmentációs technikának a hátránya, hogy időigényes, és a megalkotott 3D modell felszíne lépcsőzetes lesz, mivel szoftveresen nem engedett a felületi burkológörbék simítása, korrekciója (3/A ábra).

- Az automatikus szegmentálás során a szoftver jelöli ki a kép egyes területeit a beállításoknak megfelelően. A leggyakoribb beállítás a szürke árnyalat bizonyos tartományának (threshold) kijelölése a teljes képen [6]. Ennek a technikának az előnye, hogy nagyon gyors, hátránya azonban, hogy az elkészült 3D modell zajos lesz, és így sok utómunkálatot igényel a későbbiekben. Ennek oka, hogy a kép nemcsak az adott modellezni kívánt területen tartalmazza a kijelölt szürkeárnyalat-tartományt, hanem attól független pontokban 

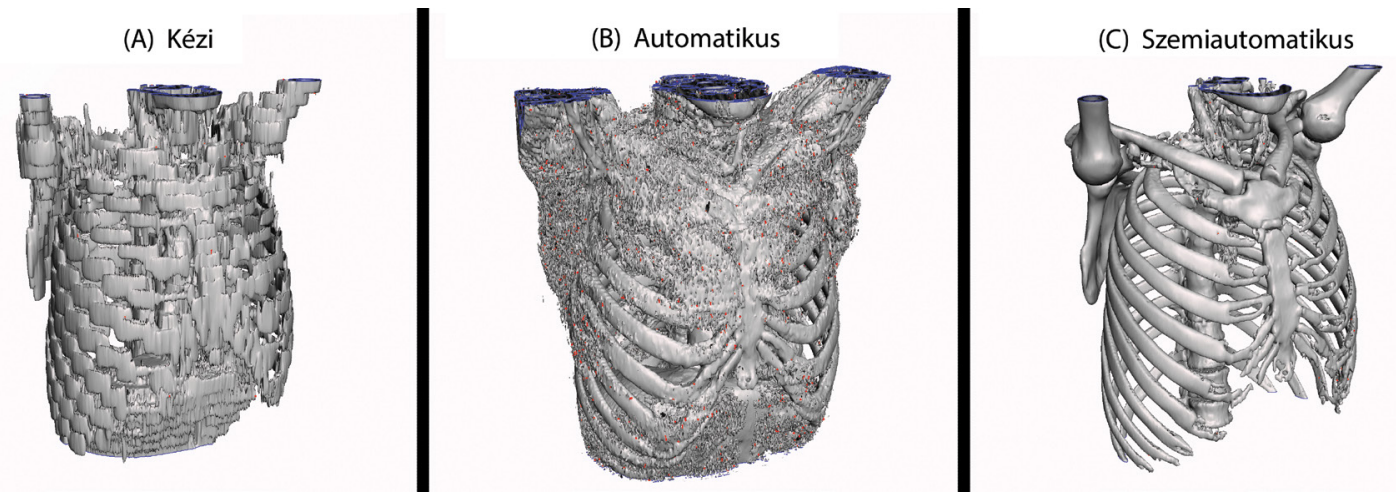

3. ábra

\begin{abstract}
Különböző szegmentálási technikák képi megjelenítése
Magyarázat: A manuálisan szegmentált modellek (A) az esetek többségében orvosi szempontból nem használhatók, mivel az egyes rétegek lépcsőzetesen épülnek egymásra, és a modell anatómiai pontossága nagymértékben csökken. A teljesen autonóm szegmentálás során (B) az adott szürke árnyalat a DICOM-fájl teljes térfogatában kijelölésre kerül, így bár anatómiailag minden fontos részlet kijelölésre kerül, a képi megjelenítés során a nagy mennyiségű mútermékképződés miatt, nem lehet látni a modellen az anatómiai képletek határait és kiterjedésüket. Munkacsoportunk által a MATLAB programnyelven kifejlesztett 3D szemiautonóm szegmentálás (C) eredményét lehet látni. Összehasonlítva az előző két szegmentálási technikával, látható, hogy pontos anatómiai kijelölést és az egyes struktúrák éles elkülöníthetőségét teszi lehetővé
\end{abstract}

is, melyek a modellezés során mint zaj jelentkeznek (3/B ábra).

- A harmadik metódus a szemiautonóm szegmentáció. Ekkor a manuális és az automata szegmentálási technikák előnyei kombinálódnak. Azaz gyorsan, anatómiailag pontos és zajmentes 3D modelleket lehet létrehozni $(3 / C$ ábra). A szemiautonóm technikán belül munkacsoportunk MATLAB-alapú forráskódot használ. A Kálmán-szúrő elvét [7] módosított formában alkalmazva nemcsak az adott szürkeárnyalat-tartományt választja ki a DICOM-fájlok rétegeiben, hanem az egyes pontok és az azok szomszédságában lévő pontok közötti rekurzív becslést végezve jeleníti meg a kijelölésre szánt anatómiai területet. Azaz a kijelölési területnek megfelelően a beállított paraméterek figyelembevételével az adott struktúrát (ROI) jelöli ki az adott matematikai formulát alkalmazva:

$$
\begin{gathered}
\mathrm{F}_{\mathrm{k}}=\frac{\partial f(\mathrm{k})}{\partial x} \cdot \mathrm{x}=\mathrm{x}(\mathrm{k} \cdot \mathrm{k}), \\
\mathrm{H}_{(\mathrm{k}+1)}=\frac{\partial f(\mathrm{k}+1)}{\partial x} \cdot \mathrm{x}=\mathrm{x}(\mathrm{k}+1 \cdot \mathrm{k}),
\end{gathered}
$$

ahol az $\mathrm{F}_{\mathrm{k}}$ az állapotátmeneti mátrix (state-transition matrix), amely meghatározza a kijelölési tartományt, a $\mathrm{H}_{(\mathrm{k}+1)}$ az a megfigyelési vagy teljesülési mátrix (observation matrix), mely $(\mathrm{k}+\mathrm{l})$ pontban korrigálja a kijelölési tartományt. Használva a módosított Kálmán-szúrőt, komplex anatómiai struktúráknál, illetve tumorinfiltrációnál lehetôség nyílik a szövethatárok pontosabb differenciálására, így pontosabb 3D rekonstrukcióra $[6,7]$.

A következő lépésben a kijelölt területekből virtuális 3D objektumot készítünk. A folyamat során térhálót definiálunk a kijelölt térfogati rétegek burkológörbéi mentén, melyet meghatározott nagyságú háromszögek alkotnak (a 2/D ábra inzertrésze). A későbbiekben ezen háromszögek koordinátáit vektorgrafikus formátumban mentjük (Standard Triangle Language, STL), melyekből aztán a modelleket nyomtathatjuk, vagy virtuális valóság megjelenítésére alkalmas eszközön kivetíthetjük.

\section{D modell alkotása}

A szegmentálás során létrejött objektumot elő kell készíteni nyomtatásra vagy a modellek sebészi döntéstámogatás céljával történő bemutatására. Az utómunkálatokat két csoportba sorolhatjuk. Az első csoportba a technikai javítások, a másodikba a modell klinikai értékelése tartozik. A technikai javításoknál a legfontosabb követelmény, hogy a képalkotásból származó voxelek izotropikusak legyenek, azaz a tér mindhárom dimenziójában egyenlő legyen a kiterjedésük. Az anizotropikus képeket első lépésben szimmetrikus képekké kell transzformálni úgy, hogy lényegi adatvesztés ne történjen az átalakítás során. Az adatvesztés ugyanis gyakran az elkészített 3D modell geometriai torzulását jelenti, így a modell alkalmatlanná válik orvosi felhasználásra. Ezt követi a modell felületét burkoló háromszögek geometriai ellenőrzése. Az invertálódott (a modell belső és külső felszíne felcserélődik, megnehezítve a virtuális megjelenítést, és lehetetlenné téve a 3D nyomtatást) és szétszakadt felszínek szoftveres kijavítása történik. A továbbiakban a modellben található zajt és a mútermékeket elimináljuk. A mútermékek egyik leggyakoribb oka a fémeszközök jelenléte (például elektróda, beültetett csavarok, lemezek stb.), illetve maga a kontrasztanyag. Az utóbbi esetben a vénásan adott kontrasztanyag magas koncentrációja okozza a mútermék képződését, mely a nem megfelelő korrekciók mellett lehetetlenné teheti a jobb oldali vénás rendszernek - beleértve a jobb kamrát is - a pontos anatómiai 3D leképezését. Ezt követôen kerül sor a virtuális 3D modell klinikai ellenőrzésére. 


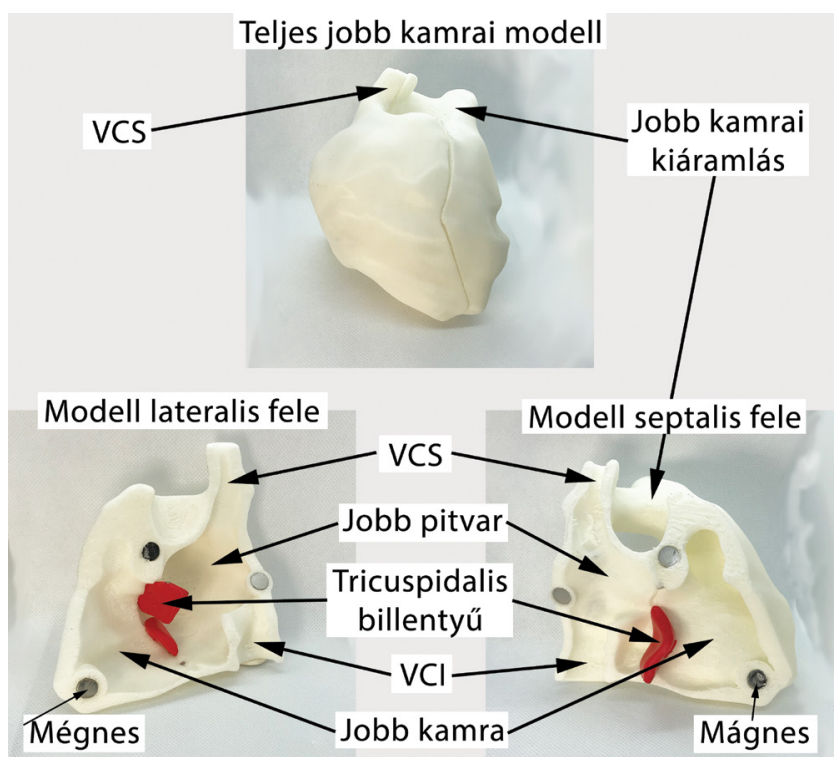

4. ábra

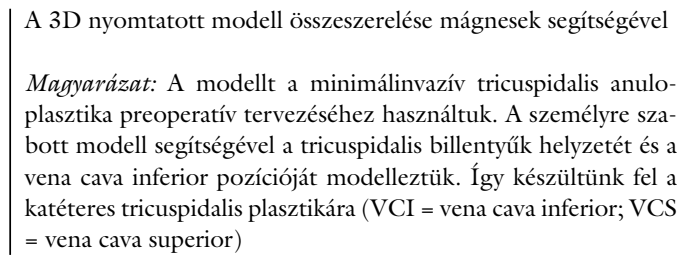

\section{Minőségi kontroll}

Gyakorlatunkban a modellek nyomtatása előtt minden esetben klinikai kontrollt végzünk, amelynek során a virtuális modellek multidiszciplináris megbeszélése történik. Radiológus, sebész, belgyógyász és a 3D tervezést és nyomtatást végző szakemberek klinikailag is felülvizsgálják a virtuális $3 \mathrm{D}$ modelleket. Ekkor a várható mútéti szituációhoz igazítjuk a modelleket. Ha kell módosítás, vagy pontosítás történik a modelleken, csak ezt követően kezdjük el a nyomtatásukat. A modellek készítése során ugyanis a legfontosabb követelmény, hogy a legpontosabban mutassák a valóságot. A 3D modellek nem torzíthatnak, mert a sebészi terápia felállítása közben a pontatlan modellek többet árthatnak, mint amennyit segítenek. A nyomtatott modelleken az egyes részek szétszedhetők, ezeknél az egyes darabokat mágnesekkel illesztjük össze. Így a beavatkozás tervezése során szétszedhetjük a modelleket, csakúgy, mintha a mútét közben rétegről rétegre haladnánk az elváltozás felé. Majd pontosan összeszerelhetjük a modellt, amelynek egyes darabjait a mágnesek tartják a helyükön a valós anatómiai szituációnak megfelelően (4. ábra).

Mellkasi tumoros mútéteknél a tumor anatómiai kiterjedése és a környező szövetekkel való kapcsolata (az infiltráció mértéke) a modell hangsúlyos része. Így ennek a területnek a lehető legpontosabb kidolgozására kell törekedni, hogy a valós anatómiai szituációt prezentálja a modell. A további, a betegséggel nem összefüggő szervek, például a scapula vagy az aortaív és a supraaorticus ágak modellezésekor is elsődleges szempont az anatómiai és méretbeli pontosság, a részletgazdagság azonban másodrendû. Ezzel időt és a nyomtatáskor anyagot spórolhatunk.

\section{$3 D$ nyomtatás}

A 3D nyomtatás a prototípus-készítés, vagy más néven additív gyártástechnológiák csoportjába tartozó eljárás. Sokan a negyedik ipari forradalom megkerülhetetlen eszközének tartják, mind ipari, mind orvostechnológiai szempontból [8-10]. Az eddigi gyártási technológiákkal ellentétben nem egy vagy több darab megmunkálásából

1. táblázat |Az orvosi használatra alkalmas legelterjedtebb 3D nyomtatási technológiák - összefoglaló táblázat

\begin{tabular}{|c|c|c|c|c|c|c|}
\hline $\begin{array}{l}\text { A nyomtatás } \\
\text { alapanyaga }\end{array}$ & Technológia & Előnyök & Hátrányok & Felbontás & Gyorsaság* & Orvosi alkalmazhatóság \\
\hline $\begin{array}{l}\text { Termoplaszti- } \\
\text { kus műanyag }\end{array}$ & FDM $^{\mathrm{a}}, \mathrm{SLS}^{\mathrm{b}}$ & $\begin{array}{l}\text { Egyszerű } \\
\text { nyomtatókezel- } \\
\text { hetőség, magas } \\
\text { ár-érték arány, } \\
\text { rövid nyomtatási } \\
\text { idő, könnyű } \\
\text { felületkezelés }\end{array}$ & $\begin{array}{l}\text { Alacsony felbontás, } \\
\text { sok támasztóelem- } \\
\text { nyomtatás, } \\
\text { a modellek felszíne } \\
\text { porózus, } \\
\text { törékeny }\end{array}$ & $60-350 \mu \mathrm{m}$ & $6-8$ óra $/ 340 \mathrm{~g}$ & $\begin{array}{l}\text { Az anatómiai szituáció } \\
\text { vizualizációjára használható } \\
\text { 3D modellek létrehozása }\end{array}$ \\
\hline $\begin{array}{l}\text { Fotopolimer } \\
\text { gyanta }\end{array}$ & $\begin{array}{l}\text { SLAc }^{c}, \mathrm{DLP}^{\mathrm{d}}, \\
\text { PolyJet }\end{array}$ & $\begin{array}{l}\text { Simább felület, } \\
\text { nagy felbontás, } \\
\text { részletgazdag } \\
\text { modellezés }\end{array}$ & $\begin{array}{l}\text { A nyomtató nehéz } \\
\text { kezelhetősége, } \\
\text { drága és időigényes } \\
\text { nyomtatás, } \\
\text { sok utómunkát igényel }\end{array}$ & $16-150 \mu \mathrm{m}$ & 22-30 óra/340 g & $\begin{array}{l}\text { Negatív öntőminták } \\
\text { nyomtatása, } \\
\text { mútéti sablonkészítés, orvosi } \\
\text { eszközök prototípusgyártása }\end{array}$ \\
\hline Fém & $\mathrm{SLM}^{\mathrm{c}}, \mathrm{EBM}^{\mathrm{f}}$ & $\begin{array}{l}\text { Igen kemény és } \\
\text { ellenálló } \\
\text { modellek, } \\
\text { magas felületi } \\
\text { megmunkáltság }\end{array}$ & $\begin{array}{l}\text { Lassú nyomtatási idő, } \\
\text { nehéz utólagos felületi } \\
\text { megmunkálás, drága }\end{array}$ & $16-150 \mu \mathrm{m}$ & $30+$ óra $/ 340 \mathrm{~g}$ & $\begin{array}{l}\text { Beültethető protézisek } \\
\text { gyártása }\end{array}$ \\
\hline
\end{tabular}

Magyarázat: *A nyomtatásgyorsaságnak egy 80 kilós férfi szívének 3D nyomtatási idejét vettük. ${ }^{a}$ Fused Deposition Modeling, bSelective Laser Sintering, 'Stereolithography, ${ }^{\mathrm{d} D i g i t a l}$ Light Processing, ${ }^{\mathrm{c} S e l e c t i v e ~ L a s e r ~ M e l t i n g, ~}{ }^{\mathrm{f}}$ Electron Beam Melting 
állítják elő a tárgyat, hanem rétegről rétegre haladva építik fel azt. Előnye a konvencionális ipari elóállításokhoz képest a gyorsasága és az alacsonyabb alapanyagköltség.

Orvosi alkalmazhatóságát mikrométeres nyomtatási pontossága és a nyomtatható alakzatok nagyméretű flexibilitása adja. Megfelelő nyomtatási típust választva a belső fül hallócsontjaitól a femur tökéletes másolatáig, bármely emberi szervet anatómiai pontosággal ki lehet nyomtatni. Az orvosi alkalmazásban négy típusú 3D nyomtató terjedt el. Ezen típusok a nyomtatás technológiájában, következésképpen felbontásukban, nyomtatási sebességükben és a felhasznált alapanyagban térnek el egymástól (1. táblázat).

FDM (fused deposition modeling), magyarul ömledékrétegezési technológia. Múködése során szál formájú, hőre lágyuló mûanyag nyomódik át egy hevítőfejen (extruder). A megolvadt müanyagot - vékony rétegben (100-350 m) - a nyomtató egy szúk fúvókán keresztül sajtolja a modelltérbe, ahol együtt szilárdul meg az előzó réteggel, így alakítva ki a $3 \mathrm{D}$ modellt. Az orvosi vizuális 3D modellek gyártásánál ez a technológia a legelterjedtebb. Nagy előnye a jó ár-érték arány és a gyors nyomtatási sebesség. Hátránya, hogy a legprecízebb nyomtatók felbontása is maximálisan csak a $100 \mu \mathrm{m}$-t éri el. Az anatómiai viszonyok tisztázásához és a sebészi preoperatív tervezéshez azonban ez a felbontási megfelelő [11]. Saját gyakorlatunkban anatómiai modellek nyomtatásához használjuk, ahol például a tumorok erezettségét szemléltetjük.

SLS (selective laser sintering, szelektív lézerszinterezés): a múanyaggyártás leggyorsabb és legnagyobb keménységet elérni képes 3D nyomtatási technológiája. A nyomtató munkatérben található egy kád, melyben egy henger segítségével finom szemcséjü müanyag port (poliamid) terítenek szét. Minden réteg felett egy fókuszált lézersugár halad végig, mely a megadott koordináták mentén összeolvasztja a múanyagot, így alakítva ki a 3D modellt. Nagy szakítószilárdságából és magas felbontásából (60-150 $\mu \mathrm{m})$ adódóan közkedvelt az ortopédiában vágósablonok és csontmodellek készítésénél [12]. A technológia előnye, hogy sebészi felhasználásra alkalmas müanyagot használhatunk. Így a kinyomtatott és sterilizált modelleket mütétek közben mint vágósablont használhatjuk.

PolyJet: a fotopolimer-alapú technológiák közé tartozik. Ekkor a modell felépítésekor nem hő hatására olvadnak össze a szemcsék, hanem megfelelő hullámhosszú fény a monomereket és oligomereket tartalmazó gyantát polimerizálja, és a térhálósodás közben az előző réteghez kapcsolja azt. Ez a jelenlegi legpontosabb 3D nyomtatási technológia. 16-28 $\mu \mathrm{m}$-es rétegvastagságot lehet elérni, és a kész teljes modell pontossága $\pm 50 \mu \mathrm{m}$. Ezért orvosi alkalmazhatósága a kis méretü és részletgazdag modellek kialakítása [13]. A technológia orvosi felhasználása kiterjed a negatív öntőminták nyomtatására, mütéti sablonkészítésre és az orvosi eszközök prototípusgyártására.
DMLS (direct metal laser sintering, közvetlen lézersugaras fémszinterezés): e technológia során a fémport egy nagy energiájú lézerfény megolvasztja. Ezt követően a gép vékony $(20-60 \mu \mathrm{m})$ fémpor réteget terít el a munkatérben az előző, már összeolvasztott réteg fölé, melyen a lézer ismét. A modell - az elterített fémpor vastagságától függően - 20-60 $\mu \mathrm{m}$-rel magasabb lesz. Az így elkészült fém- (orvosi fém, a leggyakrabban titán) modell a keménysége és sterilizálhatósága következtében alkalmas protézisek gyártására [14].

Munkacsoportunk is az FDM-technológiát alkalmazza a vizuális $3 \mathrm{D}$ modellek gyártásakor. A modell nyomtatását követően a modelleken utómunkálatokat kell végezni, hogy alkalmazhatók legyenek sebészi döntéstámogató eszközként. A nyomtatás során úgynevezett támasztóelemek is nyomtatódnak a modell felszínére. A filament, miközben a nyomtató az extruderen keresztülnyomja, 210-260 ${ }^{\circ} \mathrm{C}$ közötti hőmérsékleten megolvad, a filament anyagától függően [15]. Az új réteg megolvasztja az alatta lévő réteget, így biztosítva, hogy az egymásra épülő rétegek összekössenek, és a nyomtatás végén ne forgácsolódjon szét a modell. Az olvadás következtében azonban a $45^{\circ}$-os szögnél meredekebb élek elhajolhatnak, a rétegek elcsúszhatnak egymáson, következésképpen a modell használhatatlanná válik. Ezt a hibalehetőséget küszöböli ki a támasztóelemek nyomtatása, melyek a $45^{\circ}$-os szögnél meredekebb éleket támasztják alá (5. ábra). A támasztóelemek eltávolítását követően a modell összeállítása és klinikai alkalmazása következik.

\section{Eredmények}

Összesen 121 virtuális tervezés történt, ebből 49 esetben nyomtattuk ki a modelleket. A 2. táblázat tartalmazza a 3D nyomtatott modellekhez tartozó betegek demográfiai adatait, a modellek alapját képező képalkotás típusait, az esetekhez tartozó diagnózisokat és a 3D modellek indikációit. A táblázatból látható, hogy 5 (10,2\%)

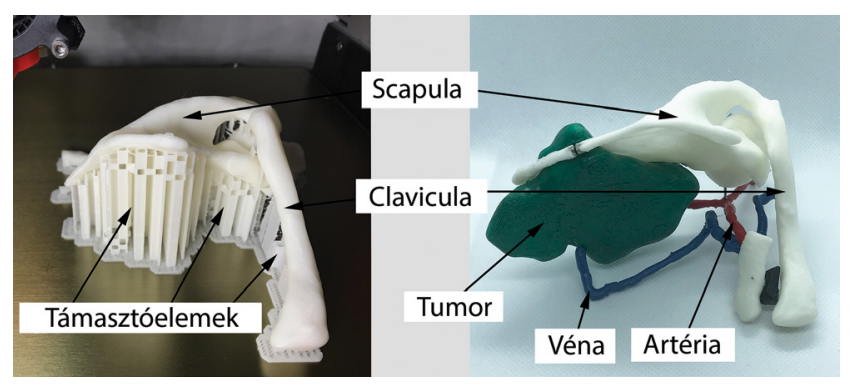
5. ábra A 3D nyomtatás lépései
Magyarázat: A létrehozott STL-fájlok 3D nyomtató segítségé- vel, úgynevezett ömledékrétegezési technológia alkalmazásával rétegről rétegre (120 $\mu \mathrm{m}$ rétegvastagsággal) kinyomtathatók. Látható, hogy támasztékok nyomtatódnak a $45^{\circ}$-nál merede- kebb elemek alá, megvédve a modelleket a magas hő deformáló hatásától. Miután a modellek nyomtatása befejeződött, a tartó- elemeket eltávolítjuk, és a részeket összeállítjuk 
2. táblázat |A 3D nyomtatott modellek indikációja és demográfiai adatai

\begin{tabular}{|c|c|c|c|c|}
\hline Nem & Életkor & Képalkotás & Diagnózis & A 3D modell indikációja \\
\hline \multicolumn{5}{|c|}{ Szívsebészeti modellezés } \\
\hline Nő & 55 & CTA & Aorta-pszeudoaneurizma & Aortafal elkülönítése a sternalis lemezektől, intraoperatív használat \\
\hline Férfi & 36 & MRI & Bal pitvari tumor & Bal pitvari hátsó fal érintettsége, sebészi rekonstrukció tervezése \\
\hline Férfi & 33 & MRI & Bal pitvari tumor & Minimálinvazív mútéti beavatkozás tervezése \\
\hline 4. Férfi & 41 & MRI & Bal pitvari tumor & Minimálinvazív mútéti beavatkozás tervezése \\
\hline Nó & 43 & MRI & Bal pitvari tumor & Minimálinvazív mútéti beavatkozás tervezése \\
\hline 6. Nő & 58 & MRI & Bal pitvari tumor & Minimálinvazív mútéti beavatkozás tervezése \\
\hline 7. Nó & 25 & MRI & Tumor a mitralis anuluson & Mitralisbillentyú-plasztika tervezése \\
\hline Férfi & 13 & CTA & Aortectasia (Marfan-szindróma) & Bentall-mütét és mellkasi rekonstrukció (Nuss-mütét) megtervezése \\
\hline Férfi & 59 & CTA & Posztinfarktusos septumdefektus & Mütéti rekonstrukció tervezése \\
\hline Nö & 61 & CTA & Posztinfarktusos septumdefektus & Mütéti rekonstrukció tervezése \\
\hline 11. Nö & 63 & CTA & Posztinfarktusos septumdefektus & Mütéti rekonstrukció tervezése \\
\hline 12. Nő & 66 & CTA & Posztinfarktusos septumdefektus & Mútéti rekonstrukció tervezése \\
\hline 13. Nő & 53 & CTA & HOCM & Balkamra-kiáramlási pálya sebészi reszekciójának tervezése \\
\hline 14. Férfi & 58 & MRI & Balkamra-aneurizma & Aneurizmarekonstrukció, vágósablon alkalmazásával \\
\hline Férfi & 59 & MRI & Balkamra-aneurizma & Aneurizmarekonstrukció, vágósablon alkalmazásával \\
\hline 16. Férfi & 74 & MRI & Balkamra-aneurizma & Aneurizmarekonstrukció, vágósablon alkalmazásával \\
\hline 17. & 59 & MRI & Balkamra-aneurizma & Aneurizmarekonstrukció, vágósablon alkalmazásával \\
\hline 18. Férfi & 16 & CTA & Coronariamalformatio & Oktatási céllal készült anatómiai rekonstrukció \\
\hline Férfi & 39 & CTA & Mechanikus múszív beültetése & Eszköz pozicionálása személyre szabott sablonnal \\
\hline 20. Férfi & 41 & CTA & Mechanikus múszív beültetése & Eszköz pozicionálása személyre szabott sablonnal \\
\hline 21. Férfi & 52 & CTA & Mechanikus múszív beültetése & Eszköz pozicionálása személyre szabott sablonnal \\
\hline Férfi & 57 & CTA & Mechanikus múszív beültetése & Eszköz pozicionálása személyre szabott sablonnal \\
\hline 23. Férfi & 60 & CTA & Mechanikus múszív beültetése & Eszköz pozicionálása személyre szabott sablonnal \\
\hline Férfi & 61 & CTA & Mechanikus múszív beültetése & Eszköz pozicionálása személyre szabott sablonnal \\
\hline Férfi & 67 & CTA & Mechanikus múszív beültetése & Eszköz pozicionálása személyre szabott sablonnal \\
\hline Nő & 50 & CTA & Mechanikus múszív beültetése & Eszköz pozicionálása személyre szabott sablonnal \\
\hline 27. Nő & 54 & CTA & Mechanikus mûszív beültetése & Eszköz pozicionálása személyre szabott sablonnal \\
\hline 28. Nö & 61 & CTA & Mechanikus múszív beültetése & Eszköz pozicionálása személyre szabott sablonnal \\
\hline Férfi & 44 & CTA & Pitvari septumdefektus & Minimálinvazív mútéti behatolás tervezése \\
\hline Férfi & 43 & CTA & Aortectasia & Aortagyök-rekonstrukció megtervezése \\
\hline Férfi & 47 & CTA & Aortectasia & Aortagyök-rekonstrukció megtervezése \\
\hline 32. Nö & 53 & CTA & Aortectasia & Aortagyök-rekonstrukció megtervezése \\
\hline Férfi & 67 & CTA & Tricuspidalis insufficientia & Minimálinvazív anuloplasztika tervezése \\
\hline 34. Nó & 60 & CTA & Tricuspidalis insufficientia & Minimálinvazív anuloplasztika tervezése \\
\hline 35. Nö & 78 & CTA & Tricuspidalis insufficientia & Minimálinvazív anuloplasztika tervezése \\
\hline Férfi & 41 & 3D echó & Mitralis insufficientia & Billentyürekonstrukció \\
\hline Férfi & 42 & 3D echó & Mitralis insufficientia & Billentyürekonstrukció \\
\hline Férfi & 55 & 3D echó & Mitralis insufficientia & Billentyúrekonstrukció \\
\hline 39. Nö & 57 & 3D echó & Mitralis insufficientia & Billentyưrekonstrukció \\
\hline Nő & 59 & 3D echó & Mitralis insufficientia & Billentyưrekonstrukció \\
\hline 41. Nö & 60 & 3D echó & Tricuspidalis insufficientia & Billentyürekonstrukció \\
\hline Férfi & 32 & 3D echó & Aortainsufficientia & Billentyúrekonstrukció \\
\hline Férfi & 44 & 3D echó & Aortainsufficientia & Billentyúrekonstrukció \\
\hline Nó & 47 & 3D echó & Aortainsufficientia & Billentyưrekonstrukció \\
\hline \multicolumn{5}{|c|}{ Mellkassebészeti modellezés } \\
\hline 45. Nő & 42 & HRCT & Tüdő bal felső lebenyi tumor & A tumor és a nagyerek kapcsolata, a tumorreszekálhatóság eldöntése \\
\hline Férfi & 41 & CTA & Tüdőhilusi tumor & A tumor és a nagyerek kapcsolata, a tumorreszekálhatóság eldöntése \\
\hline 47. Férfi & 51 & CTA & Tüdőhilusi tumor & A tumor és a nagyerek kapcsolata, a tumorreszekálhatóság eldöntése \\
\hline Férfi & 23 & MRI & Axillaris tumor & A tumor és a nagyerek kapcsolata, a tumorreszekálhatóság eldöntése \\
\hline Nő & 37 & MRI & Thoracalis neurinoma & Sebészi feltárás megtervezése (anterior vagy posterior behatolás) \\
\hline
\end{tabular}

3D ECHO = 3D ultrahang; (a 3D echóképeknél a DICOM-fájlokat használtuk, és nem közvetlenül a 3D képeket);CT = számítógépes tomográfia; $\mathrm{CTA}=\mathrm{CT}$-angiográfia; HRCT = nagy felbontású CT; HOCM = hypertrophicus obstructiv cardiomyopathia 

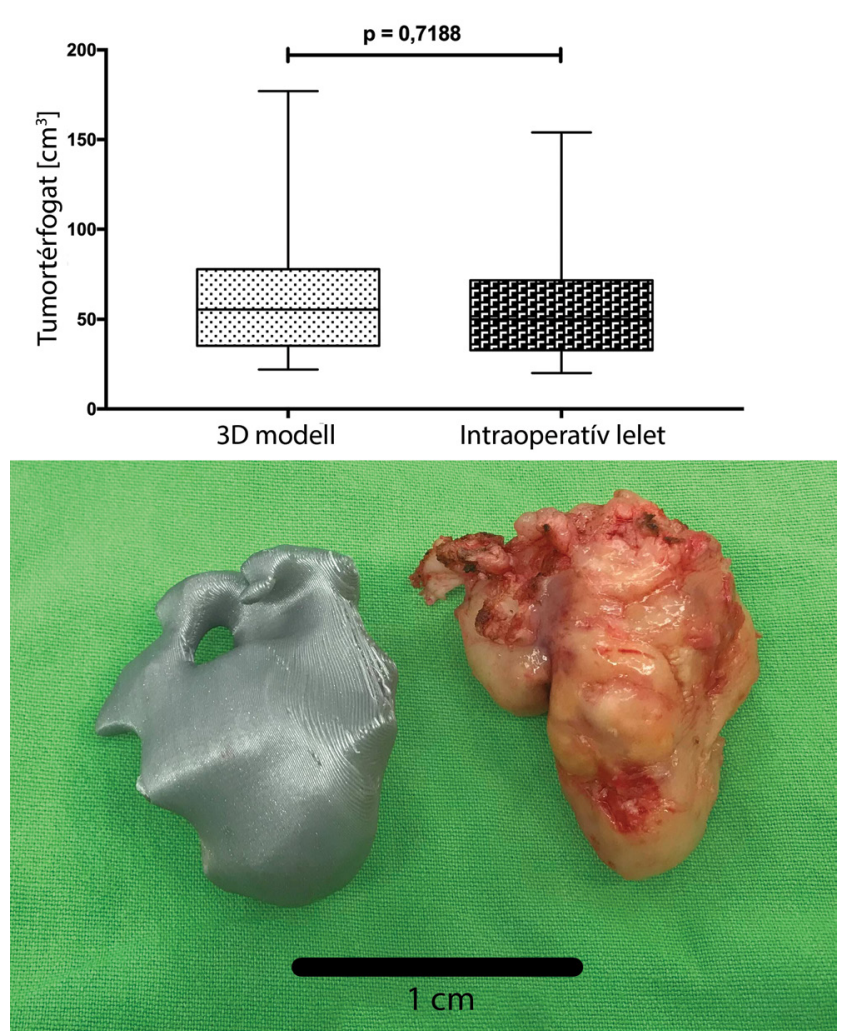

6. ábra

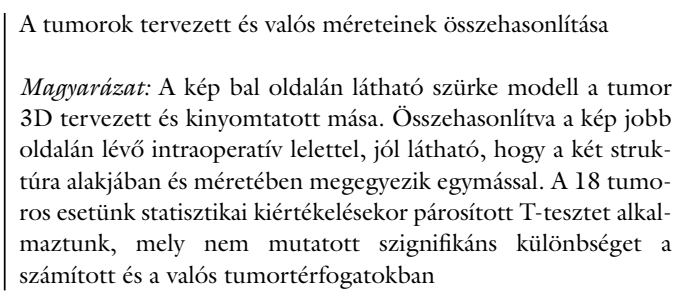

mellkassebészeti és 44 (89,8\%) szívsebészeti beavatkozásnál készült 3D nyomtatás. Betegeink átlagéletkora 49,7 év, és a férfiak aránya $57,1 \%(\mathrm{n}=28)$.

Általánosságban elmondhatjuk, hogy a tumoros eseteknél MRI-képekből dolgoztunk, mivel a szöveti felbontása jobb - összehasonlítva a többi orvosi képalkotáséval -, így könnyebb a tumort és a környező szöveteket elkülöníteni egymástól. Gadolíniumos késői halmozású MRI-felvételeket használtunk balkamra-aneurizmás betegeink 3D tervezésekor, így különítve el az élő myocardiumszövetet az ifarcerálódott területektôl. 3D szívultrahang-vizsgálatok DICOM-fájljait felhasználva mitralis, tricuspidalis és aortabillentyúket 3D rekonstruáltuk. Egyebekben a szívsebészeti tervezések túlnyomó többségénél CT-angiográfiás vizsgálatot végeztünk, hogy a nagyereket és a szív belsô struktúráit ábrázolni tudjuk.

A nyomtatott modelleket két nagy csoportba lehet osztani. Az első csoportba az anatómiai modellek tartoznak. Ezek nyomtatásakor FDM-technológiát alkalmaztunk, és mint sebészi döntéstámogató eszközök készültek. A másik csoportot a sebészi vágósablonok alkotják. Ebben a csoportban az anatómiai pontosság mellett fontos szempont maga a modell anyaga is. Ezek a sablonok ugyanis a mütét során közvetlen kapcsolatba kerülnek a beteggel. Így ebbe a csoportba (a balkamra-aneurizma mútétei és mechanikus múszív beültetése) tartozó sablonok nyomtatását SLS-nyomtatóval végeztük orvosi múanyag felhasználásával.

A modellek pontosságát az eltávolított tumorok tervezett és valós elhelyezkedése, alakja és térfogata alapján vizsgáltuk. Az összehasonlítás során összesen 18 tumoros eset 3D tervezését vettük figyelembe, ebból 11 esetben nyomtatás is történt. A tumorok tervezett elhelyezkedése, alakja és kapcsolata a környező képletekkel megegyezett az intraoperatív lelettel. Térfogatuk nem mutatott szignifikáns különbséget (6. ábra).

\section{Megbeszélés}

A virtuális modelleket $3 \mathrm{D}$ nyomtatás segítségével személyre szabott, valós méretû́ és az anatómiai szituációt pontosan mutató modellekké lehet alakítani. A 2D képi szürke árnyalatos képekhez képest a virtuális 3D modellek számos esetben többletinformációt jelenthetnek. Használatukkal lehetőség nyílik, hogy pontos, a késóbbi sebészi terápiát befolyásoló méréseket, számításokat végezhessünk. A virtuális modellek a tumorok környezeti infiltráltságának megítéléséhez és a reszekciós vonalak meghatározásához elegendők. Segítségükkel számszerúsíthető és vizualizálható a tumor kiterjedése, ami mútét közben a tumoros és ép határok elkülönítésére ad lehetőséget - ezzel segítve a teljes tumorszövet eltávolítását, így csökkentve a tumor újbóli kialakulását. Saját 18 tumoros betegünknél egyetlen esetben történt recidíva. Azonban ekkor sem lokálisan, hanem távoli áttét képződött, mely a tumor (synovialis sarcoma) természetes lefolyásával állhat összefüggésben.

A tumorsebészetben a feltárás pozicionálása és mértékének meghatározása igen fontos része a mútétnek. A jól megtervezett feltárás megkönnyíti a tumor eltávolítását. A mútéti behatolás megtervezéséhez térbeli többletinformációt adott a valós méretû $3 \mathrm{D}$ modellek alkalmazása. Ezeken a modelleken életszerúbben lehetett látni a szervek térbeli viszonyát, így a feltárások tervezésekor minden esetben készítettünk nyomtatott modellt, összesen 7 alkalommal.

Megfigyeléseink szerint a modellek mint sebészi döntéstámogató eszközök alkalmazása lerövidíti a mútéti időt, és csökkenti a vérvesztés mértékét. Ezeket a megfigyeléseket azonban statisztikailag igazolni szinte nem lehet. Kevés az olyan sebészi beavatkozás - föleg a tumorsebészetben -, amelynek során standard sebészi eljárás szerint történnek a mútétek. Így nem számszerüsítettük és nem hasonlítottuk össze a mútéti időt és a vérzés mértékét. Tendenciaként viszont levonhatjuk, hogy mind a vérzés és vérzéses szövődmények, mind a mútéti idők rövidültek. Belátható, hogy ha előre látjuk, adott esetben kézbe is foghatjuk az adott sebészi szituációt még az operáció megkezdése előtt, akkor fel tudunk rá készülni. Ső́t a mútét közben a virtuális vagy kinyomta- 
tott modellek segítségével tájékozódhatunk, így elkerülhetjük a nagyobb vérzéseket a preparálás vagy a tumor reszekciója során.

Szívsebészeti vonatkozásban a 3D tervezés mellett az úgynevezett dinamikus modellezésnek van szerepe. Preoperatív áramlástani szimulációkkal lehetőség nyílik a posztoperatív eredmények prediktálására, így egyes mütéti típusok standardizálhatóvá, következésképpen biztonságosabbá tehetők [16]. A 3D nyomtatást kihasználva lehetôségünk van az áramlástani szimulációkat ellenőrizni. 14 esetben nyomtattuk ki a modelleket, és folyadékot áramoltatva azokban ultrahanggal igazoltuk szimulációs eredményeinket, így készültünk fel a balkamra-aneurizma mútéteire és a mechanikusmüszív-beültetésekre.

Saját tapasztalatunk, hogy nem lehet kategorizálni, mikor van szükség a virtuális $3 \mathrm{D}$ modell nyomtatására. Az emberi agy térbeli rekonstrukciós és tájékozódási képességétől függ, hogy mely modellek adnak többletinformációt, ha ki vannak nyomtatva. Abban az esetben, ha több szervet, struktúrát és azok egymáshoz viszonyított helyzetét is figyelembe kell venni, a nyomtatott 3D modellek megkönnyítik a tájékozódást és így a mútét tervezését. Általánosságban elmondhatjuk, hogy a sebészi intraoperatív sablonokat és a sebészi feltárások tervezéséhez használt modelleket kinyomtattuk. A nyomtatást minden esetben megelözi a virtuális 3D modell bemutatása a beteget kezelő orvosi csapatnak. A megbeszélés közben vetődik fel a 3D modell kinyomtatásának szükségessége. Minden eset egyéni elbírálású, melyben fontos szerepet kap a mútétet végző sebész tapasztalata is. Tendenciaként elmondható, hogy a nyomtatott modellek alkalmazása a fiatal sebészek körében népszerúbb - összevetve több évtizedes rutinnal rendelkező kollégáikkal, akik elsősorban abban az esetben kérnek 3D modellt, ha az anatómia komplexitása indokolja. Egy korábban publikált cikkünkben [17] egy ilyen esetet közöltünk, amelynél a pszeudoaneurizma és a titán sternalis lemezek kapcsolatát ábrázolta a 3D kinyomtatott modell, ezzel segítve a tájékozódást a mütét közben.

További célunk, hogy a komplex vagy ritka anatómiai szituációkat oktatási céllal kinyomtassuk, és bevonjuk a graduális és posztgraduális képzésbe.

Anyagi támogatás: A jelen tanulmány megjelenését a Nemzeti Kutatási, Fejlesztési és Innovációs Hivatal támogatta (NKFIA; NVKP_16-1-2016-0017, Nemzeti Szívprogram).

Szerzői munkamegosztás: Az irodalomkutatásban, a kézirat összeállításában és megírásában a szerzők egyenlő mértékben vettek részt. A bemutatott 3D modellek készítését és azok nyomtatását $d r$. Barabás J. Imre végezte.
A cikk végleges változatát valamennyi szerző elolvasta és jóváhagyta.

Érdekeltségek: A szerzőknek a cikk megírásával kapcsolatban nincsenek érdekeltségeik.

\section{Irodalom}

[1] Chepelev L, Giannopoulos A, Tang A, et al. Medical 3D printing: methods to standardize terminology and report trends. 3D Print Med. 2017; 3: 4-11.

[2] PubMed. 3D modeling and 3D printing in medicine. Available from: https://www.ncbi.nlm.nih.gov/pubmed/?term $=3 \mathrm{D}+\mathrm{mo}$ deling $\% 5$ B Title $\% 2$ FAbstract $\% 5 \mathrm{D}+\mathrm{OR}+3 \mathrm{D}+$ printing $\% 5 \mathrm{~B}$ Title $\% 2$ FAbstract\%5D [accessed: July 27, 2019].

[3] Stiehl, JB. Acetabular allograft reconstruction in total hip arthroplasty. Part I: Current concepts in biomechanics. Orthop Rev. 1991; 20: 339-341.

[4] Barabás JI, Pólos M, Daróczi L, et al. Computer-assisted decision-making in cardiac surgery: from 3D preoperative planning to computational fluid dynamics in the design of surgical procedures. [Számítástechnikai döntéstámogató rendszer kiépítése a szívsebészetben: a 3D tervezéstől a posztoperatív eredményekig.] Magy Seb. 2018; 71: 117-125. [Hungarian]

[5] Király L. Three-dimensional virtual and printed models improve preoperative planning and promote patient-safety in complex congenital and pediatric cardiac surgery. [A háromdimenziós virtuális és nyomtatott szívmodellek megkönnyítik a komplex mútétek megtervezését és javítják a betegbiztonságot a csecsemőés gyermekszívsebészetben.] Orv Hetil. 2019; 160: 747-755. [Hungarian]

[6] Maolood IY, Al-Salhi YEA, Lu S. Thresholding for medical image segmentation for cancer using fuzzy entropy with level set algorithm. Open Med (Wars). 2018; 13: 374-383.

[7] Goliaei S, Ghorshi S, Manzuri MT, et al. A Kalman filter technique applied for medical image reconstruction. Sys Sig Dev. $2011 ; 12$ : 46-51.

[8] Walker M, Humphries S. 3D Printing: applications in evolution and ecology. Ecol Evol. 2019; 9: 4289-4301.

[9] Weinhart M, Hocke A, Hippenstiel S, et al. 3D organ models revolution in pharmacological research? Pharmacol Res. 2019; 139: 446-451.

[10] Zadpoor AA, Malda J. Additive manufacturing of biomaterials, tissues, and organs. Ann Biomed Eng. 2017; 45: 1-11.

[11] Mazzanti V, Malagutt L, Mollica F. FDM 3D printing of polymers containing natural fillers: a review of their mechanical properties. Polymers (Basel) 2019; 11: 1094-1116.

[12] Tao O, Kort-Mascort J, Lin Y, et al. The applications of 3D printing for craniofacial tissue engineering. Micromachines (Basel) 2019; 10: 480-498.

[13] Richard Z, Jackson E, Jung JP, et al. Feasibility and potential of three-dimensional printing in laryngotracheal stenosis. J Laryngol Otol. 2019; 133: 530-534.

[14] Dzian A, Živčák J, Penciak R, et al. Implantation of a 3D-printed titanium sternum in a patient with a sternal tumor. World J Surg Oncol. 2018; 16: 7-11.

[15] Tappa K, Jammalamadaka U. Novel biomaterials used in medical 3D printing techniques. J Funct Biomater. 2018; 9: 17-33.

[16] Barabás IJ, Hartyánszky I, Kocher A, et al. A 3D printed exoskeleton facilitates HeartMate III inflow cannula position. Interact Cardiovasc Thorac Surg. 2019; 29: 644-646.

[17] Kálmán B, Barabás IJ, Daróczi L, et al. Routine aortic valve replacement followed by a myriad of complications: role of 3D printing in a difficult cardiac surgical case. J Thorac Dis. 2017; 9: $1021-1024$.

(Barabás J. Imre dr., e-mail: barabasji@gmail.com) 